\title{
Geochemical Analysis of Sediments from Sahaiawei-1 Well of the Northern Delta Depobelt in the Niger Delta Basin, Nigeria
}

\author{
K. Itiowe ${ }^{1 *}$, F. A. Lucas ${ }^{2}$, E. O. Avwenagha ${ }^{1}$ \\ ${ }^{1}$ Arthur Jarvis University, Akpabuyo, Cross River, Nigeria \\ ${ }^{2}$ Department of Geology, University of Benin, Benin City, Nigeria
}

Received 30 July 2020, accepted in final revised form 28 September 2020

\begin{abstract}
Geochemical analysis of sediments from Sahaiawei-1 Well of the Northern Delta Depobelt in the Niger Delta Basin was carried out to classify the sediments, determine the provenance, tectonic setting and depositional environment. Twenty (20) ditch cutting samples between 1500 and $10730 \mathrm{ft}$. were subjected to X-ray fluorescence analysis to determine the elemental composition. The result for the classification of the sediments shows that the sediments were classified as Fe-shale and Fe-sand. The discriminant function diagrams for provenance signature and tectonic setting show that the sediments were plotted within the quartzose sedimentary provenance and passive continental margin tectonic setting fields respectively. The depositional environment using inorganic geochemistry shows that the sediments were deposited with in the continental, transitional and marine environments. This research has provided up to date information on the geochemistry of the Northern Delta Depobelt which would help in hydrocarbon exploration in the area.
\end{abstract}

Keywords: Provenance; Tectonic setting; Quartzose; Continental; Depositional; Marine.

(c) 2021 JSR Publications. ISSN: 2070-0237 (Print); 2070-0245 (Online). All rights reserved.

doi: http://dx.doi.org/10.3329/jsr.v13i1.48455 J. Sci. Res. 13 (1), 125-135 (2021)

\section{Introduction}

The Tertiary Niger Delta Petroleum Province is among one of the major hydrocarbon provinces in West Africa. The region is sited at the zone where Africa and South America separation started. The delta represents an aulacogen (a failed armed of a triple junction) that developed after rifting ceased during the Mid-Cretaceous times [1].

Geochemical analysis as a tool is been used by scientists to determine the chemical constituents that make up geological materials. Geochemical fingerprints can predict where petroleum, water and other valuable minerals can be found [2]. The use of inorganic geochemical fingerprints for the classification of siliciclastic sediments, provenance, tectonic setting and depositional environment have been carried out by different workers [2-9]. The geochemical study using X-ray fluorescence analysis for the reservoir rocks of Surma Basin in Bangladesh showed that the reservoir rocks are mainly

\footnotetext{
*Corresponding author: kiamukeitiowe@yahoo.com
} 
greywacke to lithic arenite and are from quartzose sedimentary provenance which was deposited under active continental margin setting [2]. Geochemical characterization of FE-1 Well on the Western Niger Delta Basin was carried out using laser inductively coupled plasma mass spectrometer (LA-ICP-MS) to determine the trace and rare earth elements; humid and semi humid conditions were designated for the sediments of the well [3]. The $\mathrm{Al}_{2} \mathrm{O}_{3}-\left(\mathrm{K}_{2} \mathrm{O}+\mathrm{CaO}+\mathrm{MgO}\right)-\left(\mathrm{Fe}_{2} \mathrm{O}_{3}+\mathrm{MgO}\right)$, (AKF) ternary plots revealed that the sediments of Asu River Group and Cross River Group are deposited in a continental, transitional and marine settings [4]. Major oxides from XRF analysis were used to determine the geochemistry of Ode Aye tar sand and they concluded that granite and gneisses provenance is probably the source of the tar sand [5]. Classification of Hawkesbury sandstones was achieved by using X-ray fluorescence and the sandstones were classified as quartz arenites with subordinate sublithic arenites [6]. Combined methods of fusion inductively coupled plasma (FUS-ICP) and fusion inductively coupled plasma emission/mass spectrometry (FUS-ICP/MS) were used to determine the tectonic setting of sediments from Dahomey Embayment and passive continental margin tectonic setting was decipher for area [7]. Trace and rare earth element ratios were used to determine the geochemical signatures of some sediment from the Niger Delta Basin and the conclusion was that felsic source rock is the provenance for the sediment from the Agbada Formation [8]. The silicate weathering index of some sediment from southeastern Delta suggested a low to moderate weathering of the source area during transportation [9].

Geochemical analysis of sediments from Sahaiawei-1 Well was undertaken in order to classify the sediments, determine the provenance, tectonic setting and depositional environment in a holistic manner which hitherto has not been used by any researcher in the Northern Depobelt. These variables under study are important in understanding the quality of our source rock, reservoir rock and the nature of the sedimentary basin which will aid in the exploration for hydrocarbon. The area of study is situated in the Northern Delta Depobelt. The well is geographically positioned between latitude $6^{\circ} 15^{\prime} \mathrm{N}$ and longitude $5^{\circ} 05^{\prime} \mathrm{E}$ (Fig. 1).

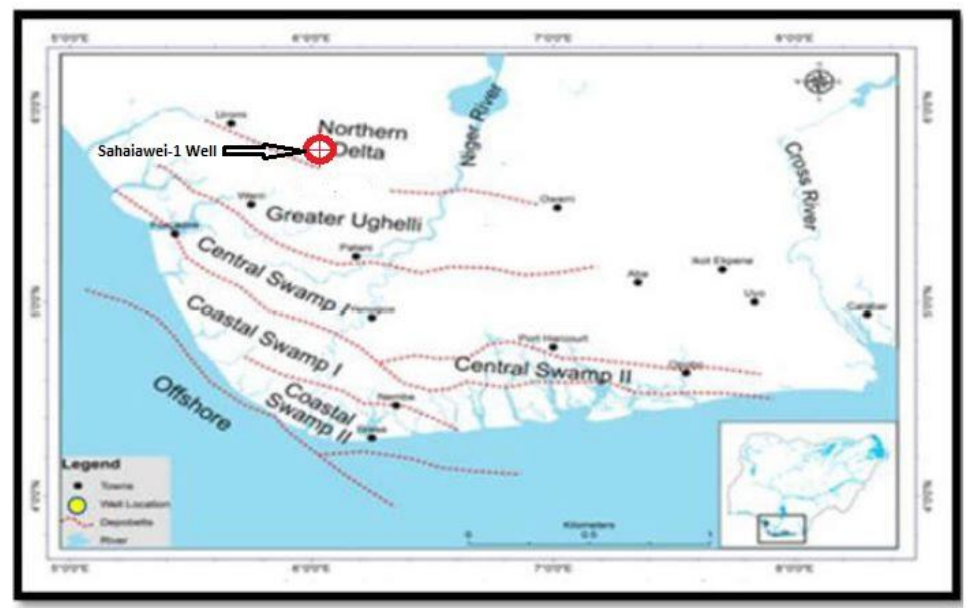

Fig. 1. Location map of study area [10]. 


\subsection{Geologic setting of the study area}

The Niger Delta Geology has been studied in recent times by researchers and oil companies because of its hydrocarbon potential and economic importance. Many writers have summarized the basic geology, lithology, stratigraphy, depositional environment, structural setting and among others.

The Niger Delta general geology was outlined by Short et al. [1]. They gave a detailed write up on the origin of the Niger Delta. They established that the tertiary deltaic sediments comprise of an upward-coarsening regressive association of deposits that are strongly diachronous (Eocene to Recent). The sediments in the Niger Delta are divided into Marine Akata, Paralic Agbada and Continental Benin Formations (Table 1). The deposition of the three formations occurred in each of five off lapping sedimentation cycles that comprise the Niger Delta [1]. These cycles (depobelts) are 30-60 km wide and has prograded $250 \mathrm{~km}$ southwest over the oceanic crust into the Gulf of Guinea and are defined by synsedimentary faulting that occur in response to variable interplay of subsidence and sediment supply rate [11,12].

Table 1. Age and formations of the Niger Delta Sedimentary Basin (modified after [1]).

\begin{tabular}{|c|c|c|c|c|c|}
\hline \multicolumn{3}{|c|}{ Subsurface } & \multicolumn{3}{|c|}{ Surface outcrop } \\
\hline $\begin{array}{l}\text { Youngest } \\
\text { Known age }\end{array}$ & Formation & $\begin{array}{l}\text { Oldest } \\
\text { known age }\end{array}$ & $\begin{array}{l}\text { Youngest } \\
\text { Known age }\end{array}$ & Formation & $\begin{array}{l}\text { Oldest } \\
\text { known age }\end{array}$ \\
\hline & Benin Fm. & & Holocene & Alluvium & \\
\hline Recent & $\begin{array}{l}\text { Afam Shale } \\
\text { Mem. }\end{array}$ & Oligocene & $\begin{array}{l}\text { Ear. Holo. To } \\
\text { Late Pleistoc. } \\
\text { Plio./Pleist. }\end{array}$ & $\begin{array}{l}\text { Deltaic Plain } \\
\text { Deposits }\end{array}$ & Miocene? \\
\hline Recent & Agbada Fm & Eocene & Miocene & $\begin{array}{l}\text { Ogwashi- } \\
\text { Asaba Fm. }\end{array}$ & Oligocene \\
\hline & & & Eocene & Ameki Fm. & Eocene \\
\hline & $\begin{array}{l}\text { Akata Fm. } \\
\text { Imo Shale } \\
\text { Nsukka Fm. }\end{array}$ & $\begin{array}{l}\text { Eocene } \\
\text { Paleocene } \\
\text { Maestrich. }\end{array}$ & $\begin{array}{l}\text { L. Eocene } \\
\text { Paleocene } \\
\text { Maestrich. }\end{array}$ & $\begin{array}{l}\text { Imo Shale } \\
\text { Nsukka Fm. } \\
\text { Ajali Fm. }\end{array}$ & $\begin{array}{l}\text { Paleocene } \\
\text { Maestrich. } \\
\text { Maestrich. }\end{array}$ \\
\hline Recent & $\begin{array}{l}\text { Equivalent } \\
\text { not known }\end{array}$ & & $\begin{array}{l}\text { Campanian } \\
\text { Camp./Mae. } \\
\text { Conia/Santo. } \\
\text { Turonian } \\
\text { Albian }\end{array}$ & $\begin{array}{l}\text { Mamu Fm. } \\
\text { Nkporo Sh. } \\
\text { Agwu Shale } \\
\text { Ezeaku Shale } \\
\text { Asu River Gp. }\end{array}$ & $\begin{array}{l}\text { Campanian } \\
\text { Santonian } \\
\text { Turonian } \\
\text { Turonian } \\
\text { Albian }\end{array}$ \\
\hline
\end{tabular}

\section{Materials and Methods}

Twenty (20) ditch cutting samples were taken from the shaly and sandy shale intervals of interest between 1500 and $10730 \mathrm{ft}$. Moisture content was removed from the ditch cutting samples by oven drying it for $4 \mathrm{~h}$ at $60{ }^{\circ} \mathrm{C}$. Arget pulverizing machine (planetary micro mill pulverisette 7) was used to mill the samples. In order to ensure homogeneity of the samples, the milled (pulverized) samples were passed through 75 micron mesh sieve. $25 \mathrm{~g}$ of the powdered samples were packed and labeled into sample cups. The sample cups 
were placed inside the Energy Dispersive X-ray Fluorescence (EDXRF) spectrometer for the analysis.

The samples were analyzed for elemental components (12 major oxides and 36 trace/REE) using energy dispersive X-ray fluorescence spectrometer at Nigeria Geological Survey Agency Kaduna, following procedure of [13,14].

The following set of conditions was made as the machine was switched on.

- Elemental composition determination

- Nature of the samples to analyzed as lose powder

- The current used as $25 \mathrm{kv}$ for major oxides, $25 \mathrm{kv}$ for the trace elements/rare earth metals.

- Selected filters were "kapton" for major oxides, Al-thin for elements.

- Measurement time for each sample was $100 \mathrm{sec}$.

- The flow chart showing the procedure for X-ray fluorescence analysis is shown below (Fig. 2).

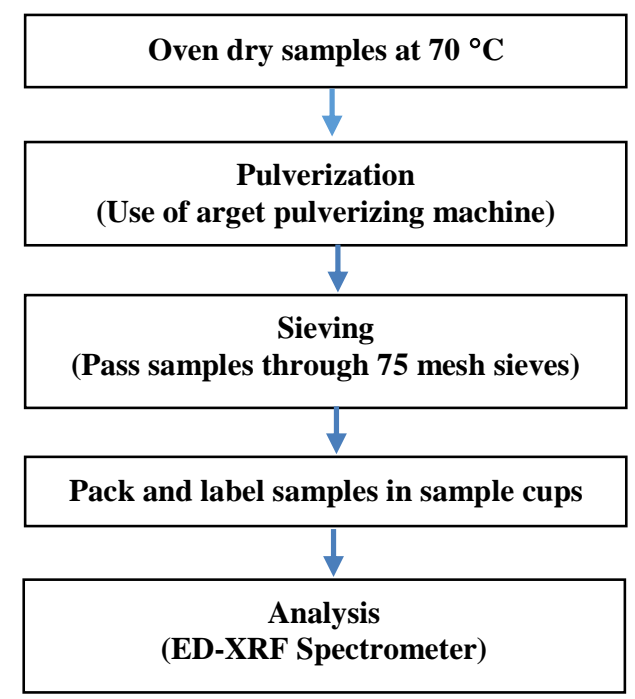

Fig. 2. Procedures for X-ray fluorescence analysis.

\section{Results and Discussion}

\subsection{Lithological description of formations in Sahaiawei-1 Well}

\subsubsection{Nsukka formation}

The formation occurs between 9120 and $10730 \mathrm{ft}$. (Fig. 3). It consists of light to dark grey shale with fissile, which is an indicative of quiet and oxygen deficient environment. The composition of the shale and high microfauna indicates marine environment of deposition and the formation dates late Maastrichtian age [15]. 


\subsubsection{Imo shale}

This formation lies between 7560 and $9120 \mathrm{ft}$. interval. The shale that occurs within this formation is mainly fine grey, fissile with light and dark colors at different intervals (Fig. 3). Iron oxide, finely dispersed coal fragments with some plant debris are common in this formation. The fissile nature of the shale is an indicative of quiet and anoxic condition. A marine environment of deposition is considered for the Imo Shale due to its fine grain and high foraminifera content that dates Paleocene age [15].

\subsubsection{Akata formation}

This formation lies between 5700 and $7560 \mathrm{ft}$. interval (Fig. 3). The shale is brownish to dark in colour at some depth. Iron oxide and coal are also found at some depth within this zone. There is also high amount of foraminifera recovery within this zone which is an indicative of marine environment of deposition [15].

\subsubsection{Agbada formation}

This formation occurs between 1800 and $5700 \mathrm{ft}$. interval (Fig. 3). The formation is composed of shale, sandy shale, shaly sandstone and sandstone. The grain sizes range from fine to very coarse grain. The sedimentological description reveals the grain sizes are angular to round and are poorly to well sorted. Iron oxide, mica, pyrite are minerals present within this zone. The sand within this zone tends to increase in thickness toward the top. Based on the percentage of shale to sand from the ditch cuttings analysis, paralic to transitional environment of deposition is considered for this formation.

\subsubsection{Continental sand}

This zone lies above the Agbada Formation (Fig. 3). The grain sizes range from fine to pebble which are angular to round. Iron oxide and about $10 \%$ coal are present within this sand. From the foraminifera biostratigraphy the sand dates Eocene age [15]. Based on the percentage of shale to sand ratio from the ditch cutting analysis, the environment of deposition is considered to be continental environment.

\subsection{Major oxide composition for Sahaiawei-1 Well}

The result for the major oxides (wt. \%) varies widely (Table 2). The range and average values of major elemental oxides are as follows: $\mathrm{SiO}_{2}(69.00-18.10$, average 41.72), $\mathrm{CaO}$ (25.00-0, average 4.40), $\mathrm{MgO}$ (1.05-0, average 0.402), $\mathrm{SO}_{2}$ (16.00-2.15, average 5.918), $\mathrm{BaO}\left(18.60-0\right.$, average 3.601), $\mathrm{K}_{2} \mathrm{O}(2.80-0.28)$, average 1.509), $\mathrm{Na}_{2} \mathrm{O}(0.98-0.02$, average 0.445), $\mathrm{TiO}_{2}$ (3.00-0.60, average 1.536), $\mathrm{MnO}\left(0.24-0\right.$, average 0.078), $\mathrm{P}_{2} \mathrm{O}_{5}(0.003-0$, average 0.00065), $\mathrm{Fe}_{2} \mathrm{O}_{3}\left(10.26-3.90\right.$, average 5.669), $\mathrm{Al}_{2} \mathrm{O}_{3}$ (21.00-9.60, average 15.75) and Lol (18.42-4.08, average 13.72). 


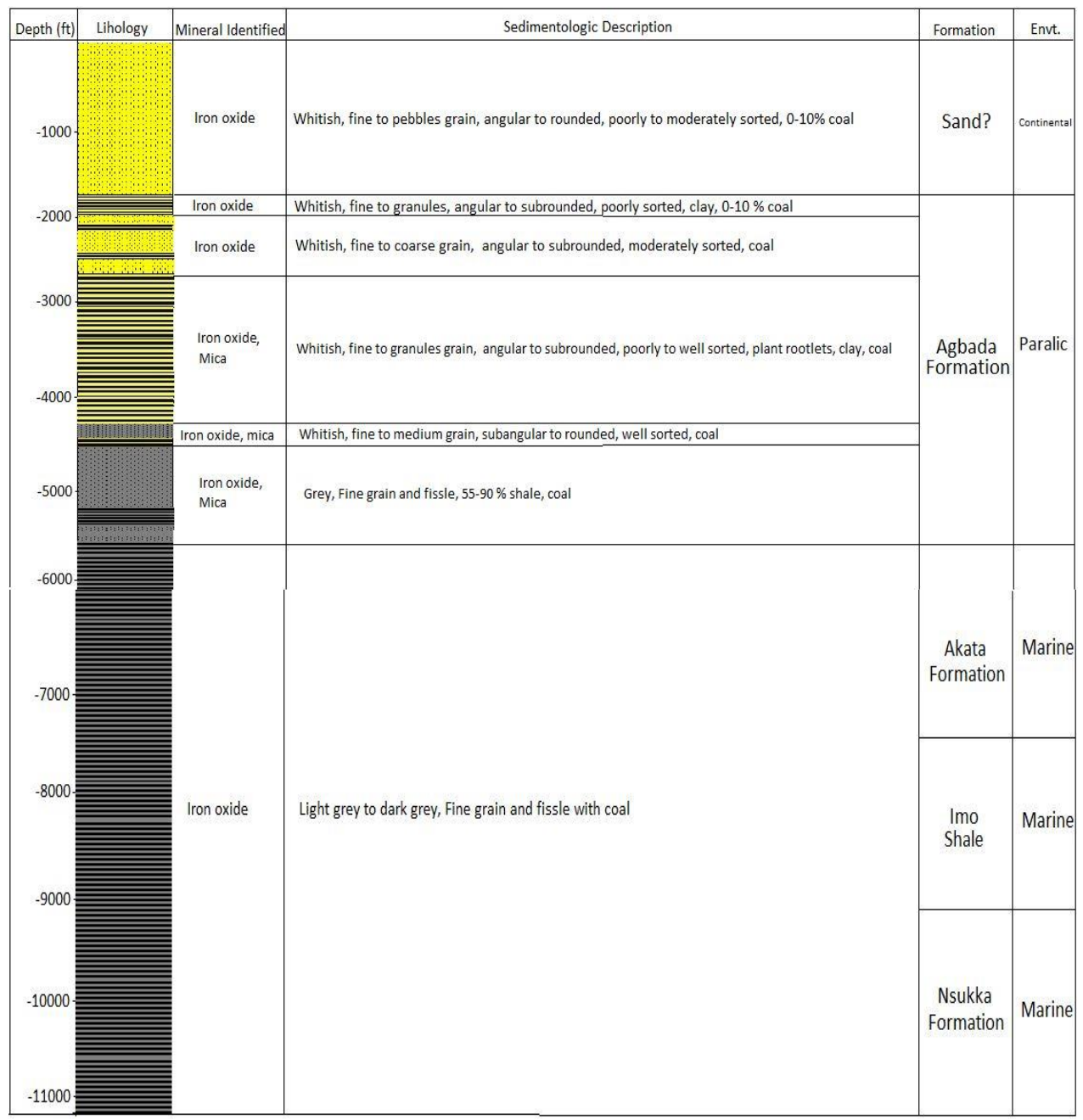

Fig. 3. Lithological description for Sahaiawei-1 Well.

Table 2. Major oxide composition for Sahaiawei-1 Well.

\begin{tabular}{lllllllllllllll}
\hline $\begin{array}{l}\text { Oxides } \\
\begin{array}{l}\text { Comp. } \\
(\%)\end{array}\end{array}$ & $\mathrm{SiO}_{2}$ & $\mathrm{CaO}$ & $\mathrm{Mgo}$ & $\mathrm{SO}_{3}$ & $\mathrm{BaO}$ & $\mathrm{K}_{2} \mathrm{O}$ & $\mathrm{Na}_{2} \mathrm{O}$ & $\mathrm{TiO}_{2}$ & $\mathrm{MnO}$ & $\mathrm{P}_{2} \mathrm{O}_{5}$ & $\mathrm{Fe}_{2} \mathrm{O}_{3}$ & $\mathrm{Al}_{2} \mathrm{O}_{3}$ & $\mathrm{LOI}$ \\
\hline 1680 & 42.00 & 0.19 & 0.04 & 16.00 & 0.07 & 0.28 & 0.06 & 0.65 & 0.21 & 0.003 & 8.01 & 17.90 & 14.20 \\
1860 & 45.00 & 0.35 & 0.002 & 8.20 & 0.10 & 0.80 & 0.02 & 1.29 & 0.24 & 0.002 & 10.26 & 14.34 & 16.00 \\
2640 & 47.80 & 2.11 & 0.87 & 2.15 & 0.08 & 1.00 & 0.40 & 0.77 & 0.02 & nd & 4.06 & 20.02 & 18.04 \\
3060 & 46.90 & 1.87 & 0.74 & 3.55 & nd & 0.85 & 0.04 & 1.40 & 0.025 & 0.0007 & 6.03 & 20.00 & 18.04 \\
3360 & 49.40 & 2.10 & 0.05 & 4.40 & 0.10 & 1.00 & 0.50 & 1.91 & 0.01 & nd & 6.81 & 17.60 & 16.80 \\
3540 & 45.91 & 2.21 & 0.30 & 6.10 & 0.17 & 1.02 & 0.20 & 1.70 & 0.04 & nd & 5.11 & 17.20 & 14.60 \\
4380 & 69.00 & 0.53 & 0.010 & 3.20 & 0.14 & 0.98 & 0.21 & 1.03 & 0.079 & 0.001 & 3.15 & 14.90 & 4.08 \\
4500 & 40.40 & 0.827 & 0.015 & 6.93 & 0.23 & 1.50 & 0.031 & 1.55 & 0.038 & nd & 4.79 & 18.08 & 18.42 \\
4860 & 43.10 & 2.10 & 0.05 & 4.40 & 0.10 & 1.00 & 0.50 & 1.91 & 0.01 & nd & 6.81 & 17.61 & 16.80 \\
5160 & 41.20 & 1.54 & 0.45 & 4.21 & 0.20 & 2.13 & 0.45 & 3.00 & 0.02 & 0.002 & 8.02 & 18.50 & 16.98 \\
\hline
\end{tabular}




\begin{tabular}{llllllllllllll}
\hline 5700 & 38.40 & nd & nd & 4.26 & 0.33 & 1.67 & 0.72 & 1.97 & 0.01 & nd & 8.20 & 21.00 & 17.60 \\
6240 & 39.90 & 18.90 & 0.12 & 5.31 & 1.00 & 0.98 & 0.44 & 1.21 & nd & 0.002 & 5.13 & 9.60 & 15.00 \\
6780 & 40.11 & 6.70 & 0.68 & 5.10 & 1.20 & 1.93 & 0.44 & 1.70 & 0.07 & nd & 4.53 & 19.20 & 15.02 \\
7440 & 40.85 & nd & 1.05 & 3.10 & 1.80 & 2.80 & 0.84 & 1.96 & 0.57 & 0.001 & 6.60 & 15.10 & 14.20 \\
7920 & 40.60 & nd & nd & 5.68 & 0.99 & 2.30 & 0.98 & 2.70 & 0.054 & 0.002 & 7.03 & 15.00 & 14.60 \\
8700 & 40.80 & 6.41 & 1.01 & 6.19 & 1.10 & 2.77 & 0.68 & 2.67 & 0.093 & nd & 6.70 & 16.02 & 15.78 \\
9300 & 34.80 & 2.69 & 0.23 & 6.08 & 18.60 & 2.07 & 0.80 & 0.60 & nd & 0.001 & 4.07 & 17.00 & 9.40 \\
9960 & 33.80 & 6.65 & 1.02 & 9.10 & 18.20 & 2.01 & 0.70 & 0.85 & nd & 0.0003 & 3.90 & 13.00 & 7.80 \\
10200 & 36.40 & 8.0 & 0.88 & 9.50 & 12.50 & 2.04 & 0.60 & 1.10 & nd & nd & 4.17 & 13.00 & 11.06 \\
10620 & 18.10 & 25.00 & 0.54 & 4.90 & 15.10 & 1.04 & 0.50 & 0.75 & 0.067 & nd & 3.71 & 6.12 & 16.71 \\
\hline \multicolumn{6}{l}{ Lol = Loss on ignition, nd $=$ Not detected } & & & & & & & &
\end{tabular}

\subsection{Classification of the sediments}

The sediments of Sahaiawei-1 Well which belong to the Agbada Formation, Akata Formation, Imo Shale and Nsukka Formation were classified using $\log \left(\mathrm{SiO}_{2} / \mathrm{Al}_{2} \mathrm{O}_{3}\right)$ against $\mathrm{Log}\left(\mathrm{Fe}_{2} \mathrm{O}_{3} / \mathrm{K}_{2} \mathrm{O}\right)$ [16] (Fig. 4). The sediments fall within the Fe-shale and Fe-sand regions, which is an indication that Sahaiawei-1Well could be rich in minerals containing iron such as illite, jarosite, pyrite and chlorite. The result is not in agreement with the quartz arenite, lithic arenites and Fe-rich sand that was deciphered by Amiewalan et al. [3] on the onshore part of the western Niger Delta Basin. This could be as a result of the nature of the sediments that were analysed or the depobelt were the study was carried out.

\subsection{Provenance of the sediments}

Provenance is the source or original area where sediments are derived. The purpose of any sedimentary provenance study is to determine the history of sediments from their parent rocks to the final point of deposition. Discriminant function diagram for provenance signature was used to differentiate the source of the sediments into four provenances [17]. They are the felsic igneous provenance, intermediate igneous provenance, mafic igneous provenance and quartzose sedimentary provenance. The plot of the two discriminant functions is based on the oxides of $\mathrm{Al}, \mathrm{Mg}, \mathrm{Ca}, \mathrm{Ti}, \mathrm{Fe}, \mathrm{K}$ and $\mathrm{Na}$, which were used to differentiate the provenance into four provenance regions. The plot of the discriminant functions using raw oxide was used to discriminate the sediments from the well (Fig. 5).

Discriminant Function $(\mathrm{DF} 1)=-1.773 \mathrm{TiO}_{2}+0.607 \mathrm{Al}_{2} \mathrm{O}_{3}+0.76 \mathrm{Fe}_{2} \mathrm{O}_{3}-1.5 \mathrm{MgO}+$ O.616 CaO $+0.509 \mathrm{Na}_{2} \mathrm{O}-1.224 \mathrm{~K}_{2} \mathrm{O}-9.09$

Discriminant Function $(\mathrm{DF} 2)=0.445 \mathrm{TiO}_{2}+0.07 \mathrm{Al}_{2} \mathrm{O}_{3}-0.25 \mathrm{Fe}_{2} \mathrm{O}_{3}-1.42 \mathrm{MgO}+$ $0.438 \mathrm{CaO}+1.475 \mathrm{Na}_{2} \mathrm{O}+1.426 \mathrm{~K}_{2} \mathrm{O}-6.382$ 


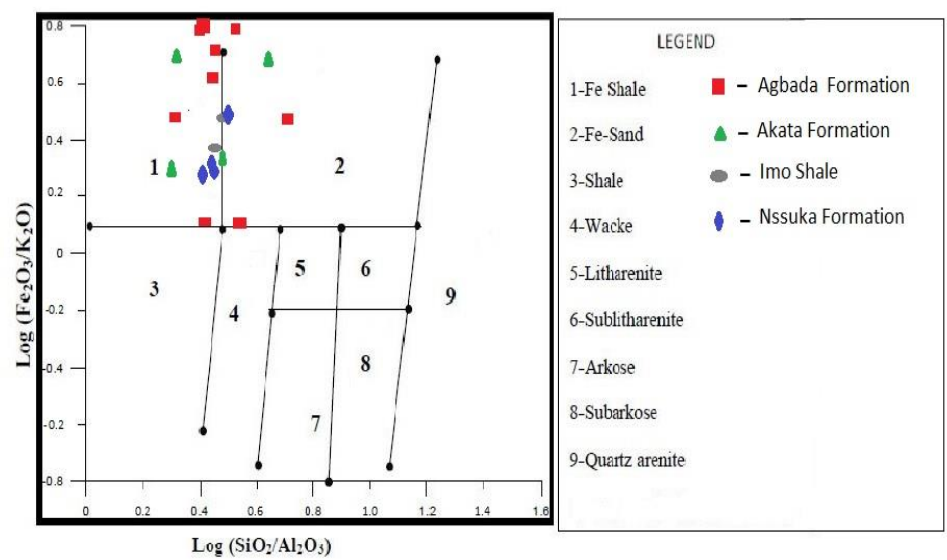

Fig. 4. Classification of sediments from Sahaiawei-1 Well [after 16].

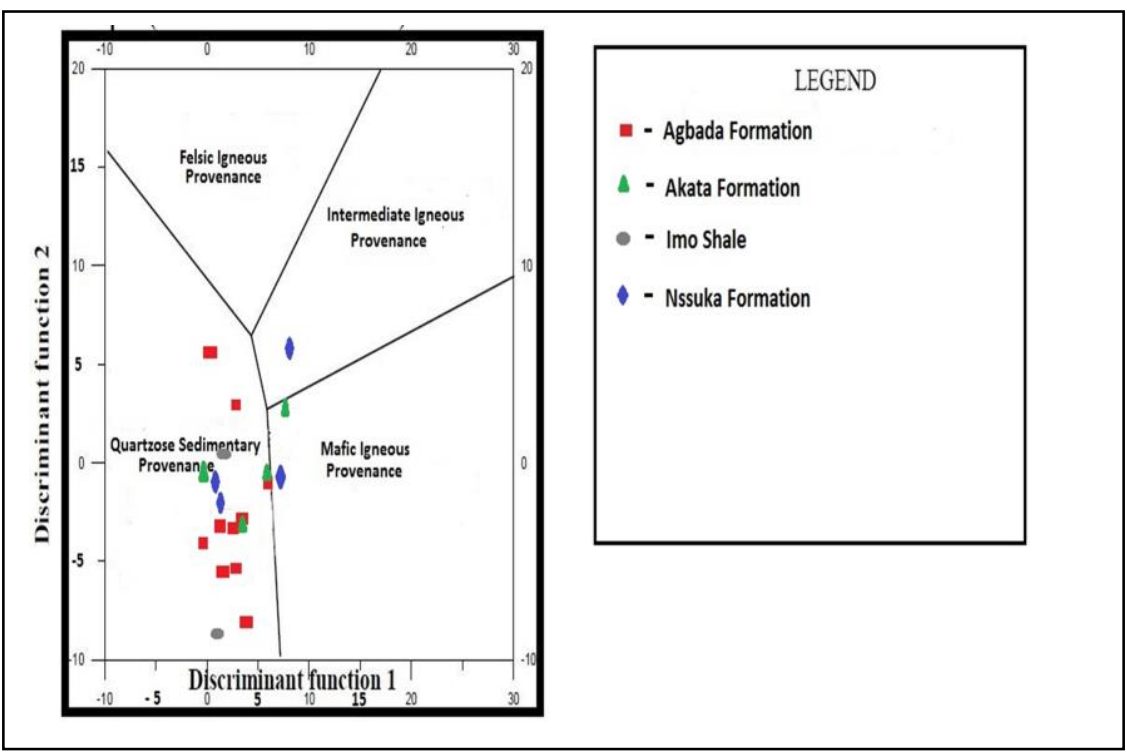

Fig. 5. Discriminant function diagram for the provenance of sediments using raw oxide [after 17].

The plot reveals that the Agbada, Akata, Imo and Nsukka sediments of Sahaiawei-1 Well were majorly source from quartzose sedimentary provenance and with little contribution from intermediate igneous provenance and mafic igneous provenance.

Quartzose sedimentary rocks commonly comprise of silicate minerals and rock fragments that are carried by moving water and are deposited when these water come to rest [2]. It could be that the sediments from this well were derived mainly from a nearby sedimentary terrane which could be sediments from the nearby Benue Trough or other existing sedimentary basins, which are now deposited in the Niger Delta Basin. 


\subsection{Tectonic setting}

Discriminant function diagram for tectonic setting after [17] was carried out to decipher the tectonic setting of the study area. There are three major tectonic settings according to Roser et al. [17]; they are as follows: active continental margin, passive continental margin and oceanic island arc. The active continental margins are those zones that experience active tectonic activities and are characterized by mountain belts, earthquakes and volcanic activities; passive continental margins are those areas that are not tectonically active; while oceanic island arc or fore-arc or back-arc basins are adjacent to a volcanic-arc and they develop on oceanic or thin continental or oceanic crust.

The plot of $\log \left(\mathrm{K}_{2} \mathrm{O} / \mathrm{Na}_{2} \mathrm{O}\right)$ and $\mathrm{SiO}_{2}$ for the sediments reveals that the sediments fall within the passive continental margin (Fig. 6). This passive continental margin is in agreement with the tectonic setting of the Niger Delta Basin $[3,18]$. Passive continental margin are zones that are not tectonically active, they are not know for reoccurrence tectonic activities such as mountain belts, earthquakes and volcanic eruption. Hence, this passive margin is favourable for oil and gas formation.

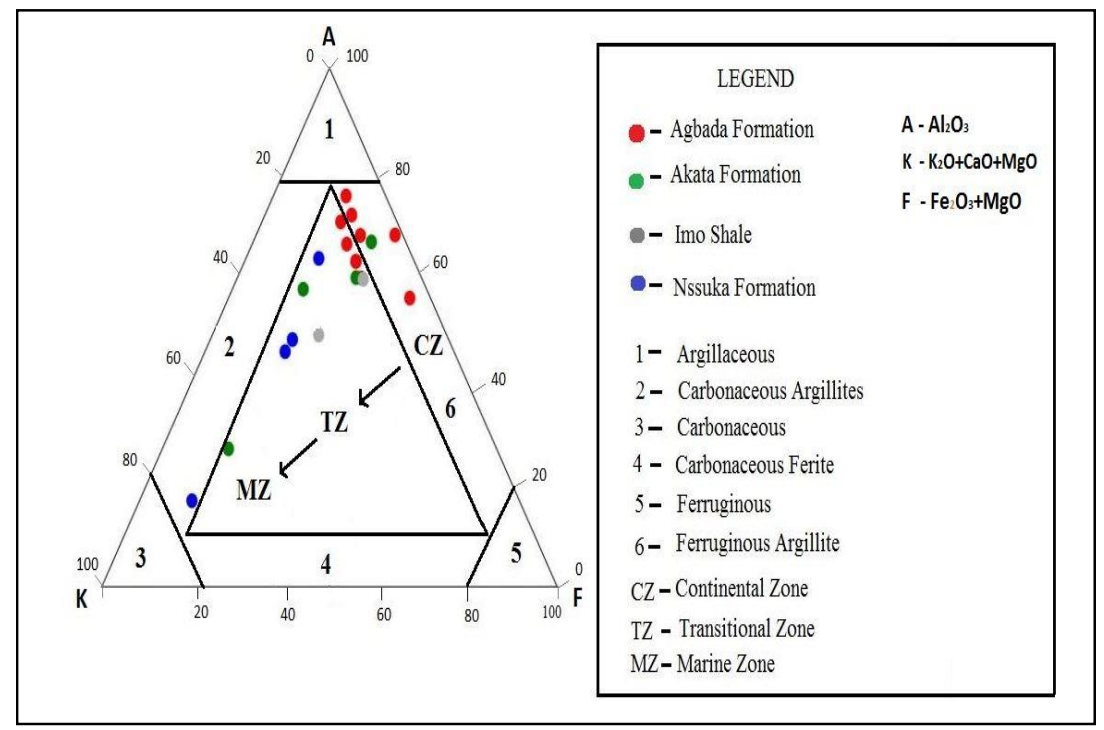

Fig. 6. Discrimination function diagram for tectonic setting for sediments of Sahaiawei-1 Well [after 17].

\subsection{Depositional environment from inorganic geochemistry}

Depositional environment was determined using the AKF $\left(\mathrm{Al}_{2} \mathrm{O}_{3}-\left(\mathrm{K}_{2} \mathrm{O}+\mathrm{CaO}+\mathrm{MgO}\right)\right.$ $\mathrm{Fe}_{2} \mathrm{O}_{3}+\mathrm{MgO}$ ) plot (Fig. 7). The sediments from Sahaiawei-1 Well were plotted with in the continental, transitional and marine zones, this is in agreement with the depositional environment interpretation from Sahaiawei-1 Well lithostratigraphic model (Fig. 3). 


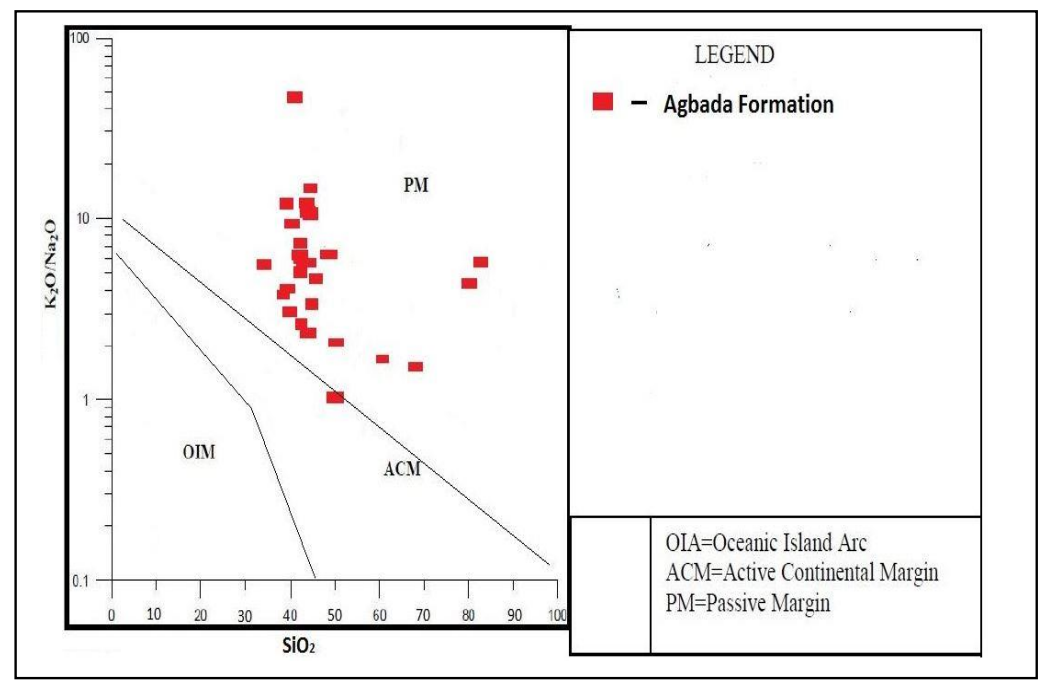

Fig. 7. $\mathrm{AKF}\left(\mathrm{Al}_{2} \mathrm{O}_{3}-\left(\mathrm{K}_{2} \mathrm{O}+\mathrm{CaO}+\mathrm{MgO}\right)-\left(\mathrm{Fe}_{2} \mathrm{O}_{3}+\mathrm{MgO}\right)\right)$ ternary plot for depositional environment [after 19].

\section{Conclusion}

Geochemical analysis has been carried out on Sahaiawei-1 Well to classify the sediments, determine the provenance, tectonic setting and depositional environment. The study reveals that $\mathrm{SiO}_{2}$ is the dominant major oxide which constitutes averagely of about 41.72 $\%$, followed by $\mathrm{Al}_{2} \mathrm{O}_{3}$ and $\mathrm{Fe}_{2} \mathrm{O}_{3}$, while the remaining oxides constitute the rest. The sediments are classified into $\mathrm{Fe}-\mathrm{Sand}$ and $\mathrm{Fe}$-Shale regions which indicate that the sediments of the well are rich in iron containing minerals. The plot reveals that the Sahaiawei-1 Well sediments were source majorly from quartzose sedimentary provenance; this could be that the sediments from this well were derived mainly from a nearby sedimentary terrane, which could be sediments from the neighbouring Benue Trough or other existing sedimentary terrane. The tectonic setting for area under study was formed in a passive continental margin tectonic setting; this kind of tectonic setting does not experience frequent volcanic eruption and earthquakes, hence favourable to oil and gas formation. The plot for depositional environment shows that the sediments were deposited within the continental, transitional and marine environments.

\section{References}

1. K. C. Short and A. J. Stauble, Am. Assoc. Petrol. Geol. Bull. 51, 761 (1967). https://doi.org/10.1306/5D25C0CF-16C1-11D7-8645000102C1865D

2. M. S. Islam, H. Mosarraf, N. J. Yeasmin, S. H. Mohammad, A. Shirin, and K. Jamiul, Geosciences 5, 1 (2015).

3. F. O. Amiewalan and F. A. Lucas, J. Appl. Sci. Environ. Manag. 24, 381 (2020). https://doi.org/10.4314/jasem.v24i2.26

4. C. A. Olubunmi and A. Y. Yusuf, J. Environ. Earth Sci. 3, 116 (2013). 
5. R. A. Obasi, H. Y. Madukwe, and O. O. Akinola, British J. Earth Sci. Res. 3, 1 (2015).

6. S. M. Zaid and F. A. Gahtani, Turkish J. Earth Sci. 24, 72 (2015). https://doi.org/10.3906/yer-1407-5

7. O. I. Ejeh, J. Geosci. Environ. Protect. 4, 56 (2016). https://doi.org/10.4236/gep.2016.46005

8. F. O. Adebayo, A. A. Segun, and Y. M. Henry, Turkish J. Earth Sci. 25, 573 (2016). https://doi.org/10.3906/yer-1512-8

9. S .O. Oni and A. S. Olatunji, Eurusian J. Soil Sci. 6, 259 (2017). https://doi.org/10.18393/ejss.297245

10. O. Odedede, J. Sci. Res. 8, 159 (2016). http://dx.doi.org/10.3329/jsr.v8i2.24236

11. H. E Doust and E. M Omatsola, Niger Delta, in Divergent/Passive Basins, ed. J. D. Edwards et al. (AAPG. Bull. Mem. 45. Tulsa Okhlahoma, 1990) pp. 201-238.

12. P. Stacher, Present Understanding of the Niger Delta Hydrocarbon Habitat, in Geology of Deltas, ed. M. N. Oti et al. (Rotterdam, A.A. Balkema, 1995) pp. 257-267.

13. A. Goto and Y. Tatsumi, Rigaku J. 13, 20 (1996).

14. J. R. Sitko, B. Zawisza, and E. Malicka, Spectrochimica Acta Part B: Atomic Spectroscopy 64, 436 (2009). https://doi.org/10.1016/j.sab.2009.04.008

15. K. Itiowe, PhD Thesis, University of Benin, Benin City, Nigeria (2019).

16. M. M. Herron, J. Sedi. Petrol. 58, 820 (1988).

17. B. P. Roser and R. J. Korsch, Chem. Geol. 67, 119 (1988). https://doi.org/10.1016/0009-2541(88)90010-1

18. M. Tuttle, R. Charpentier, and M. Brownfield, United States Geologic Survey, Open file report 99-50-H, (2015).

19. J. O. Englund and Dr. P. Jørgensen, Geologiska Föreningens i Stockholm Förhandlingar 95, 87 (1973). https://doi.org/10.1080/11035897309455428 